$\begin{array}{lllllllllllllllllllllll}\text { I } & \text { L } & \text { L } & \text { U } & \text { S } & \text { I } & \text { O } & \text { N } & \text { S } & \text { O } & \text { F } & \text { O } & \text { P } & \text { P } & \text { O } & \text { R } & \text { T } & \text { U } & \text { N } & \text { I } & \text { T } & \text { Y }\end{array}$ 
Digitized by the Internet Archive in 2014 


\section{ILLUSIONS OF OPPORTUNITY}

Employee Expectations and Workplace Inequality

Sonia Ospina

ILR PRESS an imprint of

Cornell University Press | Ithaca and London 


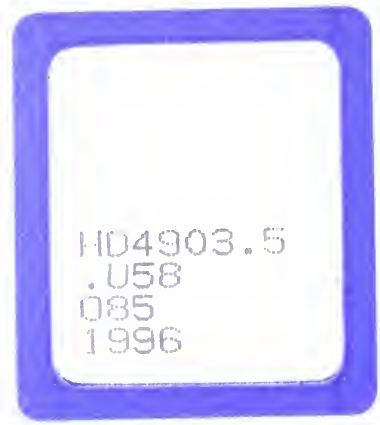

Copyright @ 1996 by Cornell University

All rights reserved. Except for brief quotations in a review, this book, or parts thereof, must not be reproduced in any form without permission in writing from the publisher. For information, address Cornell University Press, Sage House, 512 East State Street, Ithaca, New York 14850.

First published 1996 by Cornell University Press.

Printed in the United States of America

$\infty$ The paper in this book meets the minimum requirements

of the American National Standard for Information Sciences-

Permanence of Paper for Printed Library Materials, ANSI Z39.48-1984.

Library of Congress Cataloging-in-Publication Data

Ospina, Sonia Margarita, 1955-

Illusions of opportunity : employee expectations and workplace inequality / Sonia Ospina. p. $\mathrm{cm}$.

Includes bibliographical references and index.

ISBN 0-87546-356-8 (alk. paper). - ISBN 0-87546-357-6 (alk. paper)

1. Discrimination in employment-United States. I. Title.

HD4903.5.U58085 1996

$331.13^{\prime} 3^{\prime} 0973-\mathrm{dc} 20$ 
To all working women and men who struggle to make sense of their work lives.

To my parents and siblings, who helped me make sense of the world as I was growing up.

To my husband and son, who help me make sense of my present and future. 
The American society proclaims the worth of every human being. All citizens are guaranteed equal justice and equal political rights. ... As American citizens, we are all members of the same club. Yet at the same time, our institutions say "find a job or go hungry," "succeed or suffer." They prod us to get ahead of our neighbors economically after telling us to stay in line socially. They award prizes that allow the big winners to feed their pets better than the losers can feed their children. Such is the double standard of a capitalist democracy, professing and pursuing an egalitarian political and social system and simultaneously generating gaping disparities in economic well-being.

(Okun 1975:1)

We believe implicitly that everyone has the right to a rewarding, satisfying job. Opportunity, we believe, is the great satisfier; it is in our cultures and in our dispositions. ... Why isn't it more fully developed and represented in our theories and measures?

(Schneider, Gunnassen, and Wheeler 1992:65) 